ROTARY INTERNATIONAL AND THE

SELLING OF AMERICAN CAPITALISM 



\title{
ROTARY INTERNATIONAL
}

\author{
AND THE SELLING OF
}

\section{AMERICAN CAPITALISM}

\author{
Brendan Goff
}

HARVARD UNIVERSITY PRESS

Cambridge, Massachusetts

London, England

2021 
Copyright (C) 2021 by the President and Fellows of Harvard College All rights reserved

Printed in the United States of America

First printing

Every effort has been made to identify copyright holders and obtain their permission for the use of copyright material. Notification of any additions or corrections that should be incorporated in future reprints or editions of this book would be greatly appreciated.

ROTARY and ROTARY INTERNATIONAL and Design are registered trademarks of Rotary International. Rotary International was not involved with the publication of this book and the views expressed in this book do not reflect the views and opinions of Rotary International.

Jacket design: Graciela Galup

Jacket art: Rotary Club in Havana, Cuba, 1923. Courtesy of Rotary International.

$$
\begin{gathered}
9780674259119 \text { (EPUB) } \\
9780674259126 \text { (PDF) }
\end{gathered}
$$

THE LIBRARY OF CONGRESS HAS CATALOGED THE PRINTED EDITION AS FOLLOWS:

Names: Goff, Brendan, 1966- author.

Title: Rotary International and the selling of American capitalism /

Brendan Goff.

Description: Cambridge, Massachusetts :

Harvard University Press, 2021. | Includes index.

Identifiers: LCCN 2020045423 | ISBN 9780674989795 (cloth)

Subjects: LCSH: Rotary International. | Business networks. | Economics-

Sociological aspects. | Capitalism. | Publicity. | Humanitarianism.

Classification: LCC HF5001.R79 G64 2021 | DDC 369.5/20973-dc23

LC record available at https://lccn.loc.gov/2020045423 
For Joanne and Aunt Ann 
